\title{
A ciência é metapsiquismo: Fernando do Ó e o discurso espírita na imprensa de Santa Maria, RS
}

\author{
Science is metapsychism: Fernando do Ó and the spiritist discourse in the \\ press of Santa Maria, RS
}

Renan Santos Mattos*

\begin{abstract}
Resumo
Este texto trata de apresentar a posição intelectual de Fernando Do Ó, militar, advogado e espírita que atuou em Santa Maria, Rio Grande do Sul, nas décadas de 1930 a 1960, sobre espiritismo. Essas discussões foram sustentadas na análise de Pierre Bourdieu sobre as disputas percebidas no campo religioso. Destacamos as posições de Fernando do Ó a partir do que foi publicado no jornal Diário do Interior, de 1930 a 1937. Assim, propomos uma reflexão no sentido de demarcar a identidade espírita diante da pluralidade de práticas mediúnicas.
\end{abstract}

Palavras-Chave: espiritismo; Santa Maria; imprensa.

\begin{abstract}
This text comes to present the intellectual position of Fernando do Ò, military, lawyer and spiritualist who worked in Santa Maria from 1930 to 1950. These discussions were supported in the analysis of Pierre Bourdieu on perceived disputes of religious field. We highlight his positions from that was published in the Diário do Interior newspaper from 1930 to 1937, thus, we propose a reflection of his writing in the local press in order to demarcate Spiritist identity in face of the plurality of mediumistic practices.
\end{abstract}

Keywords: spiritism; Santa Maria; press.

Comunicação submetida em 17 de junho de 2018 e aprovada em 14 de dezembro de 2018.

* Mestre em História. Doutorando em História, no Programa de Pós-graduação em História da UFSC, com pesquisa sobre história do Espiritismo. Bolsista CAPES. País de origem: Brasil. E-mail: renansnatos@gmail.com 


\section{Introdução}

O espiritismo ${ }^{1}$ firmou-se no Brasil como uma alternativa religiosa que enfatizou o saber letrado e a formação erudita, com intensa valorização das práticas de estudo e leitura (LEWGOY, 2000). A plasticidade do discurso espírita, tributária do pensamento iluminista, anticlerical e livre-pensador, nascia de uma pretensa fusão entre ciência e religião, e ao integrar as disputas de campo religioso acabou delimitando um conjunto de práticas e compreensões na configuração do espiritismo em religião, e por consequência, um concepção de identidade. O problema da relação ciência e espiritismo é ressaltado por João Vasconcelos:

O Kardecismo, movimento espiritista baseado na doutrina que o pedagogo francês Allan Kardec formulou na década de 1850, é um desses objectos. Diz-se uma "religião científica" ou uma "ciência religiosa", a "ciência dos espíritos". Mas nem as ciências estabelecidas nem as religiões estabelecidas veem nele um semelhante. A pesquisa psíquica, tradição contemporânea do Kardecismo cujo apogeu se pode situar por volta de 1900 e que veio a desembocar naquilo a que hoje se chama parapsicologia, é outro desses objcetos excêntricos. (VASCONCELOS, 2003, p. 92).

Fernando do Ó esteve engajado na defesa de propostas discursivas atreladas aos ideais maçônicos e espíritas, e tendo por base o escrito nas páginas do jornal Diário do Interior, podemos compreender sua vida, seus afetos, engajamentos e sentimentos. Em um poema escrito no início dos anos 1930, Fernando do Ó presenteava-nos com registro autobiográfico, que soava, ao mesmo tempo, como esforço de instaurar uma escrita de si: "Cada palavra desse poema é um pedaço de vida, cantando na glória do meu destino. E a minha vida eu dei-a aos que me acompanham na jornada do meu sonho" (Ó, 1930, p. 3).

\footnotetext{
${ }^{1}$ Espiritualismo refere-se movimento de cunho religioso e intelectual que reunia de forma eclética, difusa, tradições e filosofias de origens as mais diversas (orientais, pré-cristãs e/ou recentemente criadas a exemplo da Teosofia de Helena Blavstsky e do Espiritismo, de $K a r d e c)$, tendo como perspectiva comum o enfrentamento dos valores da modernidade e preceitos da ciência, de um lado, e a crítica à tradição cristã, de outro (STOLL, 2003, p. 23). Já em relação ao espiritismo, consideramos que na segunda metade do século XIX, Allan Kardec, pseudônimo de Hippolyte Léon Denizard Rivail, com a publicação de uma série de livros decorrentes de suas pesquisas sobre os fenômenos espirituais daria início à constituição da doutrina que ficaria conhecida pela tríplice denominação de científica, filosófica e religiosa, a qual denominou Espiritismo. Dialogando com sistemas religiosos, doutrinas científicas, filosóficas e políticas, assumindo formas peculiares nos variados contextos em que se inseriu, revela-se uma interessante possibilidade de pensar as disputas travadas no âmbito social e cultural brasileiro. Ver: Lewgoy (2006).
} 
Quanto ao corpus documental, delimitamos como ponto central da análise a sua atuação e presença no Diário do Interior. Tal variedade engloba tanto escritos relacionados ao mundo espiritualista quanto de cunho "sociológico" que, em termos gerais, revelavam a compreensão mais ampla de ciência, peculiar aos meios espíritas. É importante ressaltar que o jornal Diário do interior foi fundando em 1911, sendo propriedade do anglicano Alfredo Rodrigues da Costa. O periódico de cunho independente e sem explícita vinculação partidária² ${ }^{2}$ reforçava o espírito do progresso que incidia sobre o espaço da cidade em decorrência da construção da Viação Férrea.

O espaço jornal é entendido espaço de sociabilidade e lugar de disputas simbólicas das diferentes vertentes religiosas, filosóficas e de pensamento bem como teatro de investidas e construção do capital simbólico3. Desse entendemos que “jornais e revistas não são, no mais das vezes, obras solitárias, mas empreendimentos que reúnem um conjunto de indivíduos, o que os torna projetos coletivos, por agregarem pessoas em torno de ideias, crenças e valores que se pretende difundir a partir da palavra escrita” (LUCA, 2005, p. 140).

Tal prática metodológica toma como referência discorrer a escrita de imprensa, visto que a imprensa lida como sentidos e representações da realidade. Nas palavras de Tânia de Luca, “os discursos adquirem significados de muitas formas, inclusive pelos procedimentos tipográficos e de ilustração que os cercam. A ênfase em certos temas, a linguagem e a natureza do conteúdo tampouco se dissociam do público que o jornal ou revista pretende atingir" (LUCA, 2005, p. 140).

\footnotetext{
${ }^{2}$ Conforme Reene Zicman, os periódicos da década de 1940/50 caracterizavam-se por sua escrita de opinião, assim, primavam por suas posições particulares, o que se costuma chamar de imprensa de opinião, carregada de elementos políticos e apaixonados, dirigindo-se a um público alvo, o jornalismo era quase um exercício literário.

${ }^{3}$ Bourdieu (1996) ressalta uma potencialidade de análise das práticas e representações religiosas, inserindo tais disputas simbólicas pelo poder, e o campo religioso definindo como lugar de tensões e espaço de luta. Logo, infere-se o poder simbólico enquanto o desejo de nomear a realidade e impor certa visão de mundo, amplamente reconhecida. Em consequência disso, as disputas simbólicas estariam atreladas a essas disposições de poder e o posicionamento em que os agentes e instituições no referido campo. Sobre o assunto ver: Bourdieu (1996).
} 
Desse modo, a problemática dessa comunicação corresponde à confluência do duelo da compreensão de si de Fernando do Ó, transitando entre o sujeito intelectual e o representante espírita. Nesses termos, o presente texto busca analisar como Fernando do Ó explica os fenômenos mediúnicos e projeta uma noção de identidade espírita 4 , capazes de enunciar as suas expectativas e sentimentos. $\mathrm{O}$ texto persegue tal pensamento como indiciário de uma estratégia do espiritismo local bem como entende tal perspectiva como integrante das disputas intestinas do espiritismo brasileiro e a questão de unificação enquanto movimento social 5 .

\section{Líder espírita e intelectual da cidade católica: um esboço biográfico}

Em 1942, uma série de reportagens sobre homens ilustres e intelectuais da cidade de Santa Maria foi organizada pelo jornalista Moacir Santana no Jornal A Razão. Na época de profícuas reconfigurações sociais e históricas do governo Vargas, à véspera da promulgação e ampliação dos direitos sociais com os direitos trabalhistas, Fernando do Ó era projetado como intelectual e homem de letras da cidade de Santa Maria em reportagem de 25 de março do corrente ano. Na chamada de Santana, deixava-se evidente a constituição de sua identidade pessoal: “Paraibano de Nascimento e Santa-mariense por gratidão" (SANTANA, 1942, p. 3).

Retomar esse registro de uma narrativa biográfica de Fernando do Ó em virtude de que pela primeira vez nos deparamos com as suas rememorações e sentimentos diante de construções e significados sobre sua trajetória. Enquanto ideólogo de si enunciava: "Nasci em Campina Grande, no brejo paraibano, nos fins do século XIX, hoje Campina Grande é uma espécie de Santa Maria do Nordeste,

\footnotetext{
${ }^{4}$ Ao problematizarmos questões de identidade e pertencimento, tomamos por referência as formulações de Stuart Hall e seu conceito de identificação e diferença. Assim, entendemos que identificação está relacionada a "um processo de articulação, uma saturação, uma sobre determinação, e não uma subsunção, mas nunca um ajuste completo, uma totalidade". Como todas as práticas de significação, ela está sujeita ao "jogo" da différance. Ela obedece à lógica do mais-que-um. A identificação opera por meio da différance, ela envolve um trabalho discursivo, o fechamento e a marcação de fronteiras simbólicas, a produção de "efeitos de fronteiras". Para "consolidar o processo, ela requer aquilo que é deixado de fora - o exterior que a constitui" (HALL, 2000, p. 106).

${ }^{5}$ Sobre a unificação o espiritismo, ver Arribas (2017).
} 
importante entroncamento ferroviário do Western. Com 15 anos de lá vim” (SANTANA, 1942, p. 3).

Assim, descortinava-se a trajetória de migração de Fernando do Ó. Chegara em 1911 ao Sul, com muitos sonhos na mente, mal alfabetizado, aos 15 anos de idade, quando ingressou na Companhia de Caçadores no estado do Mato Grosso do Sul, e em Santa Maria, em 1913, passando a compor o $7^{\circ}$ Regimento de Infantaria. Ao mesmo tempo, outro aspecto, de sua vida, seria de suma importância no contexto de redes de afetividades e afinidades.

Nessas rápidas considerações biográficas, pretendemos inseri-lo no âmbito da resistência liberal que agia na cidade diante das pretensões católicas de aproximações com o regime político varguista. E tal disputa envolveu em diferentes estratégias na tentativa de frear esse avanço. Marta Borin (2010) infere, que apesar do fortalecimento da presença do catolicismo, a polarização permanecia, e indica tais possibilidades de análise. Nesse sentido, buscamos entender esse jogo de investidas e "contrainvestidas", e de como certos agentes foram silenciados e outros passaram ser cada vez mais atuantes.

Os primórdios da organização do espiritismo de Santa Maria ocorreram com a fundação da Sociedade Espírita Paz, Amor e Caridade na localidade de Água Boa, atual distrito de Arroio do Só, em $1903^{6}$. Por outro lado, como elementos cruciais têm o ano 1921, com a inauguração da Aliança Espírita Santa-Mariense (AES), dando início à fundação de importantes instituições e campanhas de divulgação do Espiritismo, bem como uma espécie de uniformização de práticas mediúnicas. Tais constatações, podemos perceber no seu estatuto que data de 1926:

\footnotetext{
${ }^{6}$ Segundo Bruno Scherer (2013, p. 36), a organização do espiritismo ocorre diante a perspectiva de uniformização do catolicismo na cidade de Santa Maria. Situada numa região de trânsito entre o litoral e o interior do Rio Grande do Sul, a cidade destacou-se desde o início pela atividade comercial e por sua diversidade cultural. Elementos que se intensificaram com o advento da ferrovia, em 1885, com a inauguração da linha Cachoeira do Sul - Santa Maria, o que proporcionou grande desenvolvimento econômico e social para a região.
} 
Art. 1 - A «Aliança Espírita Santamariense» será constituída das entidades espíritas do município de Santa Maria da Boca do Monte, que a ela se filiarem, e de sócios individuais.

$\S$ Único - São consideradas entidades espíritas, sociedades, centros, círculos, grupos, jornais, revistas e quaisquer instituições, cujos programas observarem os princípios fundamentais da doutrina espírita.

Art. 2 - Sua sede social e jurídica é a cidade de Santa Maria da Boca do Monte - Estado do Rio Grande do Sul - Brasil.

Art. 3 - A «Aliança Espírita Santamariense» se acha filiada à «Federação Espírita do Estado do Rio Grande do Sul» e seus fins principais são:

a) Propagar, executar e defender a doutrina espírita, por todos os meios ao seu alcance;

b) Crear escolas, albergues e farmácias para os necessitados, socorrendoos, principalmente, as viúvas, órfãos e a velhice, desamparados, tanto quanto permitirem suas condições financeiras;

c) Organizar uma biblioteca, aumentando-a na proporção de suas posses, bem como uma sala de leitura para os seus associados, e que poderá ser franqueada ao publico, quando assim entenderem os seus dirigentes.

d) De propaganda - conferências ou palestras públicas, para o que serão convidados oradores de reconhecida competência. O tema, entretanto, de livre escolha destes será completamente alheio a quaisquer questões pessoais, ou de agressão a outras crenças - mantida, apenas, a liberdade de critica, moderada. (ALIANÇA ESPÍRITA, 1926, p. 1).

Em notícia de 14 de setembro de 1930, salienta-se a organização de relações sociais estabelecidas entre as diferentes instituições da sociedade Santa-mariense:

Realiza-se, hoje, no Salão Nobre da Loja Maçônica Luz e Trabalho, junto à Praça Saldanha Marinho, a primeira conferência da série organizada pela Aliança Espírita Santamariense. Esta agremiação espírita local fez distribuir, pela cidade, boletins, convidando o povo para assistir essas conferências. A de hoje que está a cargo do escritor patrício tenente Fernando do Ó, será dita em torno do tema "O que é espiritismo". (DIÁRIO DO INTERIOR, 1930, p. 3).

Assim, uma prática e uma interpretação de espiritismo foram enunciadas por tais agentes e suas instituições. Diante dessas indagações, infere-se a presença recorrente de certos agentes atuando como articuladores e líderes em favor da difusão do espiritismo e sua institucionalização na cidade, tais como Octacílio de Aguiar, Fernando do Ó, João Fontoura e Souza, Evargisto Duarte, Major João 
Scherer, Tenente Daniel Cristovão e Dr. Antônio Victor Menna Barreto, em que os mesmos assumiram-se como vozes especializadas para difundir e defender o espiritismo kardecista. Nesse universo, uma estratégia recorrente referia-se às Conferências de Propagação proferidas tanto por representantes do Espiritismo do Rio Grande do Sul quanto locais. É, nesse quesito, que refletir sobre o seu escrito permite pensar a relação entre sociedade e religião no pós-1891.

\section{Entre a ciência, religião e o sociólogo - a afirmação do discurso intelectual do espiritismo de Santa Maria}

Em 1930, Fernando do Ó completara 34 anos de idade. Vivia a rotina burocrática do posto de $1^{\mathrm{o}}$ tenente no Hospital da Guarnição de Santa Maria, o oficialato delimitava seu repertório de experiências. Trabalhava para sustentar a numerosa família, e, ao mesmo tempo em que se esforçava para dar conta do curso de direito em andamento na Faculdade de Direito de Pelotas, dividia seu tempo na presença nos espaços letrados da cidade tanto como colaborador do Jornal Diário do Interior quanto na agenda de palestras, divulgação e doutrinárias do espiritismo local.

A primeira referência de Fernando do Ó, na década de 1930, remete ao dia 5 de janeiro de 1930, sob a crônica intitulada "Do meu evangelho - Para as crianças”. Nela é possível relacionar um escritor em ascensão, comedido e comprometido com o discurso da construção de uma ética e reforma morl individual. Algo que traduz elementos cânones de uma filosofia do eu, da intimidade e da descoberta da existência. No intuito talvez de acalentar o sofrimento evocado pela desestruturação capitalista em curso e as difíceis crises econômicas, a falta de perspectiva em superar tais dificuldades. Nesse ponto, sugere frente aos caminhos tortuosos assumidos pela humanidade um conjunto de orientações: "Olha para ti mesmo, esquadrinha o teus sentimentos, mede, pesa, aquilata as tuas possibilidades psíquicas e depois diz-me se não será capaz de vencer na existência” (Ó, 1930a, p. 2). 
Tal prognóstico sugere um primeiro investimento editorial por parte de Fernando do Ó. Dando sequência a essa dimensão, no mesmo texto, passa a ponderar as posturas assumidas pelos seres humanos diante das situações enfrentadas, disciplinando os instintos, o domínio dos impulsos de forma a despertar formas do amor. Esse amor mais profundo e significativo (Ó, 1930a, p. 2).

A crônica ainda tem por objetivo amenizar a tensão e o campo de expectativas do presente contexto de corrida presidencial. Por outro lado, a leitura de Fernando do Ó chama a atenção por embrenhar-se em outros elementos da vida cotidiana. É justamente esse ponto que será discutido no bloco de artigos que, como já mencionado, sugere uma espécie de filosofia do bem e amor ao próximo como método para enfrentar as iniquidades e tensões que se alavancavam no presente contexto.

É esse movimento de significados que os primeiros textos, de forma analítica, parecem dialogar e aprofundar, apropriando-se de alguns conceitos. O contexto político e a busca de um desenvolvimento social e político trazem indícios no recorte de 1931-1933, em que a crise e a busca de soluções existenciais consubstanciam a prática intelectual de Fernando do Ó. A década de trinta será marcada por transformações de ordem política, econômica e cultural, de redefinição no papel do Estado na vida do trabalhador.

A guinada de Fernando do Ó assinalava para o grau de civilidade e novidades anunciadas pela Santa Maria, colocando-a no centro do mundo, pois, comprometido com a modernidade, circulava o artigo "Perry Machado" a respeito da turnê do famoso pianista americano Elista Machado e o violinista americano Perry Machado (Ó, 193ob, p. 2).

O diagnóstico do articulista caminhava para refletir pontos epistemológicos do Kardecismo ao tempo em que analisa os valores da época a partir da noção de genialidade e sensibilidade artística, tomando como chave de compreensão a emoção, o despertar dos sentimentos. O esforço audacioso e dantesco é capaz de 
aglutinar projeções e compreensões, mobilizando conceitos significantes dos espaços espíritas e dos meios científicos.

Nesse ponto, o primeiro elemento ressaltado é justamente da dificuldade e certa desigualdade de evolução de certos espíritos em alcançarem conexões profundas sobre a arte. E quando escreve que "A alma do artista é cousa fácil da mediocridade alcançar, entender e alavancar" (Ó, 1930b, p. 2), situa a mediocridade, e entenda-se aí o materialismo, como decorrente de um estado de espírito e ao mesmo tempo capaz de classificar o espírito de um povo. Tomado por tais princípios, enfatiza que "não que ele seja incapaz de sentir a arte, por esta é de fundo subjetivo, é obra da alma, é um prolongamento seu, se elabora no fundo misterioso do Ego. Ela a sente sem compreendê-la. Não evoluiu” (Ó, 193ob, p. 2).

A apropriação de conceitos da psicanálise endossa a pretendida conciliação científica, mobilizando elementos que articulam usos sociais de tais conceitos, e leituras da sociedade em que estava inserido. Assim, reitera-se a leitura da sociedade a partir desse recorte. Logo, nas suas palavras, "há descrença na sociedade, há incoerência, há reducionismos que os impossibilitam aprofundar sentidos que a arte evoca, sobretudo, por situá-la no âmbito da ciência do espírito”, logo, "a arte que é expressão inconfundível elaboração dos sonhos, anseios, aptidões" (Ó, 193ob, p. 2).

Nessa compreensão, ainda que velada, incisivamente afirma que a essência da arte é o metapsiquismo, atribuindo que, em última questão, "em sua face subjetiva, na sua dimensão misteriosa e profunda é simples revelação de qualidades metapsíquicas que se lançam no mundo exterior como exteriorizam pela palavra a mais transcendental ordem de ideias" (Ó, 1930b, p. 2).

Para concluir a sua construção argumentativa, os trechos finais encaminharam para pensar o contexto cultural e social da cidade de Santa Maria. Nesse quesito, atribui o nível intelectual da cidade como indicativo do êxito da atividade, enumerando a grandeza dos artistas como decorrentes de seus elevados 
espíritos, assim, "verdadeiros prodígios das individualidades que realizaram em si os superiores sonhos de beleza” (Ó, 1930b, p. 2).

Sob o título de "homem", a escrita de Fernando do Ó investiga os caminhos percorridos pela humanidade, justamente com o intuito de balançar a noção de mediocridade. Nesse sentido, o discurso intelectual desenha-se no sentido de sugerir: "o teu destino é vencer, lute, pois com desassombro, com coragem, valorosamente. A finalidade de tua missão é a grandeza em ti mesmo: - domina-te, reforma-te, progride, eleva-te" (Ó, 1930c, p. 2).

O ideal racionalista e pragmático de vincular a natureza humana como constituinte de um macrocosmo edifica a noção de ser humano enquanto arquétipo de beleza nos seguintes termos:

A natureza acena para os homens, convidando-os para o festim pagão da descoberta de suas de suas descobertas virginais: - acena aos teus irmãos para que venham deslumbrar-se no poder de tua mente, no universo em que estrelam tuas ideias gigantescas, na força criadora por excelência de tuas volições, na inexaurível fonte criadora de belezas mil que é o teu pensamento superiormente orientado para o bem e para a justiça. (Ó, 1930c, p. 2).

Dessas palavras, é possível interpretar a conciliação de elementos racionais e sagrados, em que a criação, sociedade e essência humana dialogam, propõe-se cotejar o espírito do novo homem, esse sim, capaz de ir além do aparente, capaz de dominar seus instintos, deixando de ser escravo de si, e tirano do outro. Evidenciava-se o seu entusiasmo com o pensamento espírita e científico:

Homem! Até quanto viverás escravos de teus defeitos, quando despertarás para a alforria de ti mesmo? Por que conservas inexplorada essa fonte de Amor, poder e de fé que canta misteriosa nos subterrâneos da tua alma? $\mathrm{Tu}$ és o microcosmo com as possibilidades com as possibilidades incalculáveis do macrocosmo. Há em ti tanta grandeza, tanto poder e tanta fé [...]. (Ó, 1930c, p. 2).

E ao testar sua teoria, enumera evidências do poder humano sobre o mundo social, justamente no intuito de detectar, tal qual um cientista social, indícios dos 
caminhos superficiais tomados pela humanidade. Emergia daí uma compreensão de homem e sociedade. A sociedade como uma dimensão biológica, necessária, e homem como condicionado a viver nela, por isso, viver em sociedade impele a tolerância, o amor e a solidariedade. E ao chamar atenção para o pouco tempo que vivemos na terra, Fernando do Ó ressalta a urgência de reprimir e disciplinar certos sentimentos.

Portanto, se alguém nos fez mal, causou desgostos, a nossa alma ganhou em experiência e grandeza espiritual. Por outro lado, julgava uma espécie de presentismo do momento. As ambições alargadas, de tensões fúteis, de sofrimento por males que, como chagas, nunca se fechavam, pois os mesmos insistiam em relembrar como uma forma de aumentar a volúpia da vingança e não exercitavam o perdão, concluindo da seguinte forma: "Perdoar é limpar a vida do mau que nos fizeram, e esquecer é limpar o perdão que concedemos. Homem para ser feliz perdoa, e para ser perfeito, esquece.” (Ó, 1930c, p. 2).

A partir desses registros, revela ao mesmo tempo sua ansiedade em evidenciar e notificar as descobertas científicas, mesclando elementos de juízo de valor e interpretação da sociedade, fatores que, nesse primeiro bloco, direcionamno a refletir sobre política e sociedade, vindo ao encontro à ascensão de Vargas e o governo provisório. Um texto significativo desse conjunto de impressões referia-se ao artigo intitulado Seara Abundante, em que Fernando do Ó trouxe Evaristo de Macedo como estratégia de endossar seu discurso científico e letrado, logo, a noção a apropriação do autor segue a leituras e interpretações de ciência vinculada à problemática do metapsiquismo ${ }^{7}$ e o que chama de neoespiritualismo. Nesse sentido, o autor demarcou o problema de seus estudos nos seguintes termos:

\footnotetext{
${ }^{7}$ De acordo com Vasconcelos (2003), há uma relação entre as pesquisas psicológicas e o espiritismo. Esta orientação acabaria por tornar-se dominante, embora não exclusiva, na parapsicologia da década de 1930 em diante, desdobrando-se hoje em dia em abordagens variadas que vão desde o campo da psicanálise até ao das neurociências (HESS, 1991, p. 110-111). Mas na segunda metade do século XIX e no começo do século XX, as problemáticas centrais da pesquisa psíquica eram a da existência e imortalidade da alma e a da existência de mundos imateriais, ou de planos da matéria que escapassem provisoriamente aos instrumentos de objetivação até aí desenvolvidos pelas ciências. E, como comenta a historiadora Janet Oppenheim (1985, p. 3) apud Vasconcelos (2003, p. 95-96), "alguns psiquiatras mostravam-se tão inclinados como os espiritistas a forçar os métodos da ciência para revelarem um mundo invisível e imaterial".
} 
Antes de acompanhar o mestre nessa incursão no domínio de uma ciência que nos tornou familiar, mercê de nossas convivências espiritualistas, seja nos permitido dizer que o direito como ciência sociológica e a sociologia como ciência abstrata só atingirão a sua verdadeira finalidade como de resto todo o agregado, científica de Comte, quando antes de estudar onde o direito se desdobra, compreendeu o homem, sob o duplo aspecto biológico e psicológico. (Ó, 1930d, p. 1).

Desse modo, o articulista relaciona a psicologia às pesquisas de cunho da alma, sendo assim, coloca o pensamento como o elemento central da epistemologia da ciência e justificativa a partir do olhar holístico e múltiplo do ser humano. Em suas palavras, a essência humana estaria vinculada a alma, que se potencializa no pensar, logo, "pensar, eis o trabalho incessante da alma" (Ó, 1930d, p. 1). Nesse argumento, apropria-se da noção de metapsiquismo e de contextos culturais, e sintetiza a sua abordagem analítica nos seguintes termos:

Da projeção continua do pensamento continua por milhões de almas que moram na terra resulta um formidável contingente metapsíquica que não se perde mas fica em estado vibratório no Oceano do infinito e mais adstrita ao planeta de cujo habitantes promanou. Da natureza dos pensamentos emitidos se forma a atmosfera metapsíquica da humanidade. (Ó, 1930d, p. 1).

Por outro lado, direciona-se a construir seu argumento que leva em conta o contexto cultural e a evolução espiritual, fundamentação que viabiliza esmiuçar a análises sobre os diferentes contextos sociais e culturais. Portanto, a tese levantada por Fernando do Ó consistia na dependência entre a cultura, isto é, ambiente capaz de legitimar e construir conexões, e climas psíquicos em diferentes espaços e realidades sociais. Logo, suas considerações remetem a uma espécie de lei que almeja dar conta do comportamento individual tomando com ênfase a teorização de atmosfera metapsíquica (Ó, 193od, p. 1).

O olhar classificatório e regido por tais leis do articulista compartilha de compreensões bastante recorrentes do olhar elitista, evolucionista e progressista do século XIX, cuja reforma moral legitima o seu argumento de pensar as mais variadas sociedades da sua época. A primeira característica citada corresponde ao uso e apropriação de que o clima ou atmosfera metapsíquica dos selvagens era 
respaldado em ódio, vingança, sentimentos grosseiros e brutais, impregnado de injustiça, cólera e destruição, sendo assim, os comportamentos humanos, segundo o autor, adéquam a tal aspecto. E, conclui afirmando que a barbárie aguça os conflitos e disputas entre os envolvidos.

Em relação à contemporaneidade, Fernando do Ó tece elogios calorosos à França, caracterizada como aquela construiu ambiente com pensamentos de ordem elevada, científica e filosófica, permitindo surtos de inteligência e os fulgores dos gênios. Já a Rússia czarista, para o autor, despertou sentimentos da violência, da crueldade, para a destruição, cada injustiça sofrida pelos seus párias que sustentavam o império com sacrifício, despertaram o ódio e vingança preparando o terreno para a radical transformação pretendida pela onda vermelha. A conclusão do autor, pretensamente baseado em fatos e evidências empíricas, e incisivamente, indicados pelo autor, retomados numa direção que traduz uma noção de política e concepção sociológica acerca de poder, germe de um pensamento que será posteriormente desenvolvido: "desgraçados dos governos que não modificam pela tolerância e pela cordura o pensamento de seus governados” (Ó, 1930e, p. 1).

A leitura obedecia a uma perspectiva de busca de leis, assim, os surtos violentos e revolucionários estariam condicionados a essa lógica. Fernando do Ó cita ainda para exemplificar a situação revolucionária mexicana, movida por sentimentos de vingança, do contexto revolucionário. Frente a tais considerações, intui que, considerando esse lócus de reflexão, é possível prever os destinos sociais e políticos. E após isso, passa a tecer comentários sobre a teoria de direito de Evaristo de Moraes, ingressando em discussões e debates sobre sociedade, a criminalidade e suas vertentes.

Assim, a direção assumida revela-se em atrelar comportamento humano, alma e criminalidade, alternando a explicação de cunho social e individual do ser humano, e condicionando o crime e o mal como decorrentes do pensamento humano, dos valores acumulados, da deturpação da essência. A origem da criminalidade por parte de Fernando do Ó é emblemática, justamente por propor e 
respaldar-se em conceitos espiritualistas. Assim, assinala a proeminência dos fluídos e seu impacto na relação com a consciência e ação humana: "esses fluídos, dizíamos, são o agente capaz de alterar as funções orgânicas e criar em torno do indivíduo uma atmosfera que terá a natureza dos pensamentos que a formarem" (Ó, 1930e, p. 2).

Dessa premissa, e compreensão da pessoa humana, a partir de princípios fluídicos, Fernando do Ó tenta compreender a relação entre indivíduo e sociedade, e assinala a projeção de um campo de pesquisas no âmbito da intelectualidade espírita, já que amplia a noção de ciência. Dessa maneira, detectou um campo de especialidade do moderno espiritualismo: "Que esplêndido campo que o modernoespiritualismo franqueia aos espíritas, que se não deixaram acorrentar pelos dogmas de uma ciência ou religião incapaz de desvendar o futuro humano ou manter nas almas pira sagrada da fé” (Ó, 1930e, p. 2).

Como ponto final, tinha-se como foco pensar os efeitos e a profusão dos projetos de teor político. Desse modo, afirma que um acontecimento político tomado de intensidade pode repercutir em diversas dimensões da sociedade. Por fim, atribui toda sua esperança na lei, no direito, ciência específica da conduta humana, do organismo social, e na esperança, a partir de Evaristo de Morais há de um dia "lançar as bases de uma sociedade mais humana em que os delitos e as fraquezas do homem sejam estudados a luz de conhecimentos capazes de transformar radicalmente os sentimentos da humanidade”. Le monde marche (Ó, 1930e, p. 2).

A lei, progresso, transformação. $\mathrm{O}$ eu e a sociedade ditavam as coordenadas de Fernando do Ó bem como confirmavam sua pretendida inserção no campo científico e filosófico. Nas frontes do reconhecimento e de relações afetivas, o dia a dia de Santa Maria era permeado e confrontado com entusiasmo pelos posicionamentos de Fernando do Ó. Tais leituras que traziam para o cotidiano uma roupagem cientificista, porém, carregados de elementos contraditórios de viés moralista e idealista. O discurso de Fernando do Ó permeava o interdiscurso da 
virada do século XX, de uma sociedade abalada pela Primeira Guerra Mundial, em contraste com a modernidade e em busca de novos referenciais intelectuais. É nesse horizonte intelectual que deparamo-nos com a influência de José Luís Ingenierios, que de certa forma, emprestam nuances ao olhar investigativo de Fernando do Ó.

O Homem medíocre é citado em artigo 20 de abril de 1930. Fernando do Ó principia o se texto questionando os homens que se beneficiam dos outros para galgar posições e prestígios, e ao mesmo tempo mergulham no pensamento oscilante, na vaidade, e na anuência dos homens superiores. O interessante nessa leitura é como o olhar organizacionista e biológico referencia a escrita do acadêmico de direito, capaz de categorizar os seres humanos conforme seu espírito, sua inteligência, suas ações. Logo, a essência humana estaria condicionada: "invejosos, em virtude mesmo de sua inferioridade, eles não podem ver os triunfadores subirem” (Ó, 1930f, p. 2).

Diante disso, analisamos a divulgação e a construção da autoridade de Fernando do Ó, inferimos a importância das vozes autorizadas a explicar o espiritismo no espaço público e, como nos lembra Bourdieu (1998, p.187), o “poder delegado do porta-voz cujas palavras (quer dizer, de maneira indissociável, a matéria de seu discurso e sua maneira de falar) constituem no máximo um testemunho, um testemunho entre outros da garantia de delegação de que ele está investido".

Assim, diante às perseguições aos espíritas pelas autoridades sanitárias e policiais a partir do Código de 1890, percebe-se a busca de distinção dos grupos associados à umbanda, ao candomblé e as práticas mágicas, e a categorização de "baixo espiritismo". Logo, o discurso dos intelectuais e dirigentes espíritas convergia para estratégias com o intuito tanto de demonstrar que faziam era o bem, a caridade quanto que traziam em sua prática elementos científicos. Discurso assumido e propagado pela Federação Espírita Brasileira (FEB), enfatizando a distinção entre o falso e o verdadeiro Espiritismo. 
Dessas considerações, entendemos que tal argumento não corresponde somente uma tática de defesa, mas também uma postura de combate à crendice popular, à tradição, e certo viés disciplinador, legitimando, assim, suas proposições de cunho científico e moderno. Elementos fundamentais na definição de espiritismo propagado por Fernando do Ó e sua perspectiva de análise sociológica que versam sobre a educação e a sociedade endossavam para tal estratégia assumida pelos espíritas.

Como argumenta Artur Cesar Isaia (2008, p. 149), houve um esforço de Kardec em sintonizar os postulados espíritas com as matrizes da modernidade características do século XIX, assim "a filiação aos ideais iluministas, o reconhecimento de leis mantenedoras da ordem cósmica, perfeitamente perceptíveis pelo homem, fazia com que o espiritismo encarasse a pesquisa científica como aliada no afã de comprovar a veracidade da revelação divina”.

Fernando do Ó, seduzido por tal dimensão epistemológica, embrenhou-se na divulgação de estudos sociológicos seguindo as diretrizes dominantes da intelectualidade espírita. Assim, ao atrelar a função social do sociólogo, como aquele capaz de prever, refletir e intuir, o advogado articulava ciência e revelação divina em seus escritos:

O sociólogo sabe que em tempo, com tal governo, com tas leis, em condições econômicas e financeiras tal e qual explodiu, arrasadora e violenta, uma revolução que, para logo, se tornou vitoriosa - fácil é a previsibilidade de evento idêntico, si concorrem os mesmos fatores, identifica e sabiamente coordenados, dispostos, coordenados e orientados. É bem o dever que a complexidade do fenômeno sociológico é de difícil apreensão científica, mas o sábio tem o dever de desvendar-lhe, todas as faces e fazê-lo passar pelo crivo da mais honesta observação e da mais rigorosa análise. (Ó, 1935, p. 2).

Enfim, é possível interpretar que para Fernando do Ó, o sociólogo correspondia a uma espécie de profeta. E sob essa compreensão apresenta análises acerca do campo educacional, religioso e sociológico, dialogando com autores e apresentando suas constatações comum pensamento universal e suas possíveis contribuições ao mundo social (Ó, 1935, p. 1). 
Ao descortinar tais procedimentos de investigação, criticou a postura que denominou de materialista, nesse sentido, indagou-se: "Si se pretender armar o arcabouço de uma teoria do conhecimento, desprezando-se a atividade religiosa, as forças espirituais no seu sentido maior, tem-se apenas a encarado o problema máximo da humanidade por uma frente apenas (Ó, 1935, p. 1)”.

Esse ecletismo de tendências apropriadas pelo autor é sua chave de compreensão no artigo intitulado "O sentido do Pensamento Ocidental”. A crítica de Fernando do Ó assentou-se na visão unilateral da ciência que despreza outros aspectos da vida humana. Nesse sentido, o autor ressaltou:

No indagar qual seja a direção do pensamento universal, todas as forças precisam ser estudas, principalmente as que canalizam as tendências da humanidade para uma só frente da atividade social. [...] Por que, em ultima análise, as atividades do homem devem ser encaradas em função do meio em que foi chamado a viver. (Ó, 1936, p. 1).

E ao questionar se a presença do fenômeno religioso devia ser desprezada pelo cientista, inferiu a impossibilidade de compreensão e construção de um pensamento universal complexo, ou seja, levando em conta toda a diversidade humana. Concluindo nos seguintes termos:

Porque a sociedade é formada de homens, e sendo os fenômenos sociais resultantes das atividades individuais, nunca se descobrirá o sentido, si se desprezou uma frente grandiosa de atividade, qual seja a que digas com as forças religiosas ou morais do homem. Pode se descobrir e estabelecer, com verdade, a direção do pensamento Universal, mas quando não se desprezar, no estudo dessa direção, toda uma gigantesca cadeia de fenômenos que dizem com a própria forma de atividade social. (Ó, 1935, p. 1).

\section{Considerações finais}

Sumariamente, evidenciamos aspectos de um esforço racionalista de organização da sociedade e uma leitura social proposta por Fernando do Ó, sustentado por uma perspectiva de voz autorizada a falar em nome do espiritismo, dialogando com certas temáticas em voga no presente contexto. A sua busca de sistematização racional 
acerca da análise social denotam um arcabouço que evidenciam seu ecletismo como postura política, e consubstanciam sua preocupação de ordem científica e inserção no espaço intelectual.

O instigante de Fernando do Ó é justamente o ecletismo e a tentativa de enquadramento do que o autor considera primordial no âmbito de sua militância: o espiritualismo/espiritismo. Nessa perspectiva, é pertinente situar a atuação de Fernando do Ó no âmbito da rede de pensamento que Marcos José Diniz Silva (2009, p.301-303) define como moderno-espiritualismo, portadora de um projeto social e de Humanidade. Podemos, desse modo, ressaltar que as defesas do Estado laico, da República, da liberdade religiosa e do ensino leigo faziam parte da legenda de sua militância, logo, os moderno-espiritualistas confluíam para uma fé racional e uma ciência iluminada, em que o endosso ao discurso cientificista, diagnosticando os males humanos decorrentes de seu grau evolutivo. Portanto, a ideia de reforma holística da sociedade estava associada tanto na oferta de uma variedade de ações de assistência, caridade e filantropia capazes de "aplacar as dores e misérias humanas (2009, p.303)".

Além disso, o discurso letrado enquanto bem simbólico também impele a pensar sobre o esforço em legitimar uma visão hegemônica em torno da identidade espírita, e a demarcação de seu território frente à pluralidade de práticas mediúnicas, o que inclui, sobretudo, a umbanda. Sendo assim, a exegese de uma identidade espírita almeja definir “o verdadeiro” espiritismo. Enfim, é possível perceber como esses grupos teciam suas lógicas, inventavam suas opções políticas, construíam, pensavam e liam o mundo, bem como de que modo davam sentido aos interesses em jogo (SILVA, 2012, p. 87). Logo, indícios da busca de compreensão da realidade por parte dos sujeitos históricos, envolvendo a aposta, as táticas frente ao poder assimétrico. E coloca o quanto a modernização religiosa, caracterizada pelo conhecimento em torno da pluralização da oferta religiosa no Brasil, abria possibilidades do empreendimento em torno de definir o que era e o que não era espiritismo, e a extensão do significado e ampliação do exercício da cidadania. Um novo episódio da história de Fernando do Ó, em que a luta pela defesa de sua liberdade religiosa começam a fazer parte de sua agenda de luta, fato que evidente por ocasião da constituinte de 1933 quando candidata-se a Deputado Federal. 


\section{REFERÊNCIAS}

ALIANÇA ESPÍRITA. Estatutos, Santa Maria. 1926.

ARRIBAS, C. da G. Espíritas de todo o Brasil, uni-vos! Meandros da unificação espírita na primeira metade do século XX. Religião e Sociedade, Rio de Janeiro, v. 37, n. 3, p. 150$172,2017$.

BORIN, M. Por um Brasil católico: tensão e conflito no campo religioso da República. São Leopoldo, 2010. 352 f. Tese (Doutorado em História) - Programa de Pós-Graduação em Estudos Históricos Latino-Americanos. Universidade do Vale do Rio dos Sinos.

BOURDIEU, P. A economia das trocas linguísticas: o que falar quer dizer. São Paulo: Edusp, 1998.

HALL, Stuart. Quem precisa da identidade? In: SILVA, Tomaz Tadeu (Org.). Identidade e diferença: a perspectiva dos estudos culturais. Petrópolis: Vozes, 2000. p. 103-133.

HESS, D. Spirits and scientists: ideology, spiritism and Brazilian culture. Pennsylvania. Pennsylvania State University Press, 1991.

ISAIA, A. C. Espiritismo: religião, ciência e modernidade. In: MANOEL, Ivan Aparecido; ANDRADE, Solange Ramos de (Org.). Identidades religiosas. Franca, SP: UNESPFHDSS; Civitas Editora, 2008. v. 1. p. 137-164.

LEWGOY, B. Os espíritas e as letras: um estudo antropológico sobre cultura escrita e oralidade no espiritismo kardecista. São Paulo, 2000. 352 f. Tese (Doutorado em Antropologia Social) - Faculdade de Filosofia, Letras e Ciências Humanas, Universidade de São Paulo.

LEWGOY, B. Representações de ciência e religião no espiritismo kardecista. Civitas, Porto Alegre, v. 6, n. 2, p. 151-167, 2006. Disponível em:

<http://revistaseletronicas.pucrs.br/ojs/index.php/civitas/article/view/6o>. Acesso em: $02 / 05 / 2014$.

LUCA, T. História dos, nos e por meio dos periódicos. In: PINSKY, Carla Bassanezi (Org.). Fontes históricas. São Paulo: Editora Contexto, 2005. p. 111-153.

Ó, Fernando S. Como eles sabem. Diário do interior, Santa Maria, n. 89, 20 de abril de 1930f, p. 1.

Ó, Fernando S. Do meu evangelho - Para as crianças. Diário do interior, Santa Maria, n. 4, 5 Janeiro de 1930a, p. 2.

Ó, Fernando S. Ensaios sociológicos. Diário do interior, Santa Maria, n. 211, 20 de setembro de 1935, p. 2. 
Ó, Fernando S. Homem. Diário do interior, Santa Maria, n. 55, 9 de fevereiro de 1930c, p. 2.

Ó, Fernando S. Perry Machado. Diário do interior, Santa Maria, n. 23, 29 Janeiro de 193ob, p. 2.

Ó, Fernando S. Seara abundantes. Diário do interior, Santa Maria, n. 56, 12 de março de 1930 , p. 2.

Ó, Fernando S. Searas abundantes. Diário do interior, Santa Maria, n. 55, 11 de março de 1930d, p. 1

Ó, Fernando S. O sentido do pensamento ocidental. Diário do interior, Santa Maria, n. 259, 13 de novembro de 1936, p. 1.

Ó, Fernando S. Traços. Diário do interior, n. 52, 6 de março de 1930, p. 3.

PELO ESPIRITISMO. Diário do interior, Santa Maria, n. 208, 14 de setembro de 1930, p. 4.

STOLL, S. J. Espiritismo à brasileira. São Paulo/Curitiba: Ed. USP e Ed. Orion, 2003.

SANTANA, M. Entrevista concedida por Fernando do Ó. Mais escolas, mais escolas.

Aconselha o Escritor Fernando do Ó. A razão. Santa Maria. 22 de março de 1943 p.3.

SCHERER, B. C. Ações sociais do espiritismo: A sociedade espírita feminina: estudo e caridade, Santa Maria - RS (1932-1957). 2013.87 f. Santa Maria: Trabalho de Conclusão de Curso (Bacharelado em Ciências Sociais) - Universidade Federal de Santa Maria.

SILVA, Eliane Moura . Entre religião e política: maçons, espíritas, anarquistas e socialistas no Brasil por meio dos jornais A Lanterna e o Livre Pensador (1900-1909). In: Artur Cesar Isaia; Ivan Aparecido Manoel. (Org.). Espiritismo e religiões afro-espiritismo e religiões afro-brasileiras: História e Ciências Sociais. 1. ed. São Paulo: Ed. Unesp, 2012. v. 1. p. 87-101.

SILVA, Marcos José Diniz. Moderno-espiritualismo e espaço público republicano: maçons, espíritas e teosofistas no Ceará. Tese de Doutorado. Fortaleza: UFC, 2009.

STOLL, Sandra Jacqueline. Espiritismo à brasileira. São Paulo: Ed. USP; Curitiba: Ed. Orion, 2003.

VASCONCELOS, J. Espíritos clandestinos: espiritismo, pesquisa psíquica e antropologia da religião entre 1850 e 1920. Religião e Sociedade, Rio de Janeiro, v. 23, n. 2, p. 92126, 2003.

ZICMAN. R. B. História através da imprensa: algumas considerações e metodológicas.

Projeto História - Revista do Programa de Estudos Pós-graduados em História/PUCSP. São Paulo: PUCSP, n. 4, p. 89-102, 1985. Disponível em: <https://revistas.pucsp.br/index.php/ revph/article/view/12410/8995>. Acesso em: 21 mar. 2017. 